\title{
Transparency in Portuguese Local Government: A Study of its Determinants
}

\author{
Nuno Ribeiro - Sónia Nogueira - Ivone Freitas*
}

\begin{abstract}
:
Transparency of public management is fundamental to bringing citizens closer to public managers and as such universally considered an element of good governance.

The main aim of this study is to identify the factors determining transparency in public management of Portuguese local authorities. Using the Municipal Transparency Index of 2013 and 2014, socio-demographic, political and economicfinancial variables are studied for the population of 308 Portuguese local authorities by the means of testing the previously formulated research hypotheses in the light of the agency theory.

The results show that transparency in public management of Portuguese local authorities is determined by their size, the number of individuals aged between 15 and 74 who use the internet, unemployment rate, financial autonomy and the net debt.
\end{abstract}

Key words: Local Authorities; Transparency; Accountability.

JEL classification: H11, H70, H72.

\section{Introduction}

Transparency in public management, besides being an obligation for managers and politicians, contributes to broader citizen/voter participation in exercising public functions (Tavares and Rodrigues, 2012). It is fundamental for their access to transparent information allowing on their part an assessment of the managerial efficiency as well as identification with the system.

The new form of action in local government, namely accountability to voters/taxpayers, means of communication, controlling bodies and other stakeholders in

Nuno Ribeiro; Management Applied Research Unit (UNIAG), School of Technology and Management, Polytechnic Institute of Bragança, Campus de Santa Apolónia 5300-253 Bragança, Portugal, <nunoa@ipb.pt>.

Sónia Nogueira; Research Center in Political Science (CICP), School of Public Management, Communication and Tourism, Polytechnic Institute of Bragança, Campus do Cruzeiro Av. 25 de Abril, Cruzeiro, Lote 2, Apt. 128, 5370-202 Mirandela, Portugal, <sonia@ipb.pt>.

Ivone Freitas; Softideia - Informação Automática, Lda., Rua do Pedregal 59-A 4650-094, Felgueiras, Portugal, <ivone.p.freitas@gmail.com>.

The article is processed as an output of a research project by UNIAG, I\&D unit supported by FCT - Portuguese Foundation for Science and Technology and the Portuguese Ministry of Education and Science (UID/GES/04752/2016) and Research Center in Political Science (UID/CPO/0758/2013) registered by the Portuguese Foundation for Science and Technology and the Portuguese Ministry of Education and Science through national funds. 
accompanying governments' activities, increases the attention paid to transparency and its determinants.

The principal objective of this study is to contribute to the scientific literature, seeking to answer the following research question: "what are the determining factors of transparency in Portuguese local authority management?" The main purpose is to identify, for the Portuguese local authority situation, the factors determining the level of transparency. To achieve this aim, the results of the recently developed Municipal Transparency Index (MTI) for the years 2013 and 2014 are used.

Following this introduction, the article is structured in 3 sections. Section two relates the agency theory with accountability and transparency. The third section presents the empirical analysis, stating the hypotheses and variables, how the data will be treated, and the results and discussion of the hypotheses. The last section presents the main conclusions of the study.

\section{Agency Theory, Accountability and Transparency}

Jensen and Meckling (1976) define the agency relationship as a contract through which one or more people (the principal - capital holder) hire another person (the agent - manager) to perform a service or work in their name. In this contractual relationship the principal delegates some decision-making authority to the agent, a fact that gives rise to conflicts of interest due to the separation of ownership and control. The agent does not always act in the principal's interest, which means agency costs are incurred, resulting from adopting monitoring mechanisms and residual losses.

The principal-agent dilemma involves a relational conception of accountability, bearing in mind the matter of information (Ferejohn, 1999). The problem of accountability is related to the problem of delegation, since representative democracies mirror the relation of authority between the person who delegates and the one who is delegated. The principal delegates to the agent the power to carry out something in the former's interest, and it is the agent's duty to act in the principal's interest.

The agency theory has been widely applied to the business situation, but in recent decades it has been used increasingly in other contexts, particularly in representative democracy (Ferejohn, 1986). Considering the agency theory approach to representative democracy, voters (principal) elect politicians/leaders (agents) to represent their interests through the policies proposed by governments and the guidance given to Public Administration on how to carry them out. In addition, by financing public activities, tax-payers also delegate to their representatives the decision to allocate public resources. 
From the agency theory's perspective, the lack of transparency can create an advantage for political decision-makers in achieving their objectives: agents (politicians/leaders) can have their own interests that do not always maximize their voters' well-being. Therefore, and according to the above mentioned theory, accountability takes place in the scope of an electoral democracy, according to a minimalist conception of the democratic process fundamental for the institutionalization of accountability which consists of reducing the information deficit between principals and agents by enhancing transparency.

Alt, Lassen and Skilling (2001) indicate that transparency reduces the information asymmetries between political agents and citizens/voters. The authors suggest two ways to diminish this problem: i) inform voters about the actions taken by elected politicians (Ferejohn, 1999), or ii) facilitate coordination in budget results between the bodies alternating in power.

The concept of transparency emerges as linked to the information economy, where the citizen is seen as an investor and consumer of public goods. In the view of Ferejohn (1999), the principal invests its resources in the action carried out by the agent (politicians/leaders), hoping for a positive return on the undertaken investment. The balance in the relationship between the principal (voters/taxpayers) and the agent (politicians/leaders) depends on the existence of transparent entities that are able to reduce the uncertainty of the investment (Ferejohn, 1999). As mentioned above, transparency maximizes accountability by allowing a reduction of information asymmetry between the principal and the agent, thereby ensuring a system of possible accountability through reducing public bodies' secrets. According to this approach, for the agency theory, transparency strengthens accountability in the scope of the information economy, with the citizen being seen as a consumer of public goods, i.e., financing public sector activities.

\section{Factors Determining Transparency in Portuguese Local Authority Management}

\subsection{Research hypotheses}

Based on the literature review (Ingram and Copeland, 1982; Christianes, 1999; Ferejohn, 1999; Traunmuller, 2001; Reddick, 2005; Alt, 2006; Piotrowski and Van Ryzin, 2007; Christoph, Schaltgger and Torgler, 2007; Rueda, 2007;García and García, 2008; Gallego-Álvarez, Rodríguez-Domínguez and García-Sánchez; 2010; Guillamón, Bastida and Benito, 2011; Lourenço, Jorge, Sá and Rolas, 2011; Esteller-Moré and Otero, 2012; Mendes, 2012; Pires, 2012; Alegre, Peñas, Santias and Boubeta, 2013; Vicente, Benito and Bastida, 2013; García-Sánches, FríasAceituno and Rodríguez-Domínguez, 2013; Batalha, 2014; Sol, 2013; Tavares and Cruz, 2014, and Sedmihradská, 2015), as well as the precepts of the agency 
theory, a set of research hypotheses was formulated, relating the level of transparency with certain variables considered as the potentially explanatory factors. For better understanding, the analysed hypotheses were grouped based on socio-demographic, political and economic-financial factors.

DIM - Logarithm of the inhabitants residing in the local authority.

INTER1574 - Logarithm of the number of residents aged between 15 and 74 who use the internet.

ESCOL - Percentage share of the population with higher education on the total population of the local authority.

IENV - Number of people aged 65 and over for every 100 people under the age of 15.

TXDESEMP - Number of unemployed per 100 active people.

FGOV - Dummy variable taking on the value ' 1 ' if the political party that manages the municipal executive obtained majority (more than $50.1 \%$ of the votes), otherwise '0' (zero).

IDEOL - Dummy variable with a value ' 1 ' when the municipal executive is of the right party ideology and '0' (zero) otherwise.

PARTELEI - Number of voters in municipal elections divided by the number of voters registered in the electoral rolls.

AUTFIN - Own revenues divided by total revenues.

Table 1 presents the various hypotheses, the variables to be studied, data sources and the individual expected signs.

\section{Tab. 1: Research hypotheses, variables and expected signs}

\begin{tabular}{lllll}
\hline $\begin{array}{l}\text { Research } \\
\text { ypothesis }\end{array}$ & Description & Variable & Data Source & $\begin{array}{c}\text { Expected } \\
\text { Sign }\end{array}$ \\
\hline H1 & $\begin{array}{l}\text { The level of transparency is } \\
\text { higher the higher the population } \\
\text { of the local authority. }\end{array}$ & DIM & $\begin{array}{l}\text { Pordata } \\
\text { (www.pordata.pt) }\end{array}$ & + \\
The level of transparency is \\
higher the higher the number of \\
people aged between 15 and 74 INTER1574 \\
who use the internet.
\end{tabular}




\begin{tabular}{|c|c|c|c|c|}
\hline $\begin{array}{l}\text { Research } \\
\text { ypothesis }\end{array}$ & Description & Variable & Data Source & $\begin{array}{c}\text { Expected } \\
\text { Sign }\end{array}$ \\
\hline H6 & $\begin{array}{l}\text { The level of transparency is } \\
\text { higher in local authorities with a } \\
\text { minority government. }\end{array}$ & FGOV & $\begin{array}{l}\text { CNE } \\
\text { (www.cne.pt) }\end{array}$ & + \\
\hline $\mathrm{H} 7$ & $\begin{array}{l}\text { The level of transparency is } \\
\text { higher when a left-wing party } \\
\text { governs the local authority. }\end{array}$ & IDEOL & $\begin{array}{l}\text { CNE } \\
\text { (www.cne.pt) }\end{array}$ & + \\
\hline $\mathrm{H} 8$ & $\begin{array}{l}\text { The level of transparency is } \\
\text { higher the wider the } \\
\text { political/voter participation. }\end{array}$ & PARTELEI & $\begin{array}{l}\text { Pordata } \\
\text { (www.pordata.pt) }\end{array}$ & + \\
\hline H9 & $\begin{array}{l}\text { The level of transparency is } \\
\text { higher the greater the local } \\
\text { authority's financial autonomy. }\end{array}$ & AUTFIN & $\begin{array}{l}\text { Portal autárquico } \\
\text { (www.portalautarq } \\
\text { uico.pt) }\end{array}$ & + \\
\hline H10 & $\begin{array}{l}\text { The level of transparency is } \\
\text { higher the higher the local } \\
\text { authority's net level of debt. }\end{array}$ & ENDLIQ & $\begin{array}{l}\text { Portal autárquico } \\
\text { (www.portalautarq } \\
\text { uico.pt) }\end{array}$ & + \\
\hline
\end{tabular}

Source: Authors own elaboration.

ENDLIQ - Differences between liabilities, in whatever form, including borrowings, leasing contracts and debts to suppliers, and assets, namely the cash balance, bank deposits, treasury applications and credit claims.

With respect to the dependent variable, the MTI was developed in 2013 by Transparency and Integrity, Civic Association (TIAC) and measures the degree of local authorities' transparency through analysis of the information available to citizens on their websites. Specifically, the index measures the transparency of Portuguese local authorities according to information on their composition, operation and management, as provided on the municipal websites. The index does not measure accessibility, intelligibility, the quality and assumptions of information provision, or corruption. The MTI is made up of 76 indicators consisting of dummy variables with the value of ' 1 ' when a certain item of information is provided on the local authority site and ' 0 ' (zero) otherwise.

These indicators are grouped into seven dimensions:
A. Information on the organization, social composition and functioning of the local authority (18 indicators);
B. Plans and planning (13 indicators);
C. Taxes, fees, tariffs, prices and regulations (5 indicators);
D. Relationship with society (8 indicators);
E. Transparency in public procurement (10 indicators);
F. Economic and financial transparency (12 indicators);
G. Transparency in urban planning (10 indicators). 
Ribeiro, N. - Nogueira, S. - Freitas, I.: Transparency in Portuguese Local Government: A Study of its Determinants.

\subsection{Data treatment}

To determine the relationship between each of the independent variables and the MTI, so as to study the various hypotheses defined, a multivariate analysis is performed using the STATA program.

As the linear regression model has been widely adopted (e.g., Guillamón, Bastida and Benito, 2011; Vicente, Benito and Bastida, 2013 and Tavares and Cruz, 2014) for specifying econometric models that explain the determining factors of local authority transparency, the same method is chosen in this study. More specifically, the multiple linear regression model is applied by the Ordinary Least Squares method since we expect that the various (independent) variables may explain the local authority transparency index.

According to Marôco (2010), estimation of the linear regression model can only be performed if certain assumptions are fulfilled. Therefore, various tests will be carried out to complete that analysis.

Considering MTI as the dependent variable, and the different variables already mentioned as independent, the following model will be studied:

$$
\begin{gathered}
\text { MTI }=\alpha+\beta_{1} \text { DIM }+\beta_{2} \text { INTER1574 }+\beta_{3} \text { ESCOL }+\beta_{4} \text { IENV }+ \\
\beta_{5} \text { TXDESEMP }+\beta_{6} \text { FGOV }+\beta_{7} \text { IDEOL }+\beta_{8} \text { PARTELEIT }+\beta_{9} \text { AUTFIN }+ \\
\beta_{10} \text { ENDLIQ }+\varepsilon,
\end{gathered}
$$

where DIM is dimension; INTER1574 stands for number of residents aged between 15 and 74 who use the internet; ESCOL is used for educational level; IENV expresses ageing index; TXDESEMP represents unemployment rate; FGOV expresses party fragmentation; IDEOL is used for political ideology; PARTELEIT stands for turnout; AUTFIN is financial autonomy and ENDLIQ means debt.

\subsection{Results and Discussion}

The resulting estimated model is presented in the form of the global model (SOCDEM_PLO_ECOFIN) which includes socio-demographic, political and economic-financial variables. Within partial models, each group of factors was estimated individually. Therefore, Model 1 is related to socio-demographic factors (SOCDEM), Model 2 to political factors (POL) and Model 3 to economicfinancial factors (ECOFIN).

Analysis of Table 2 reveals that for most variables, partial models present results that are quite consistent with estimations of the global model. In this context, we will now move to an analysis of results of that model (SOCDEM_POL_ECOFIN), finding that it presents an R2 of 0.214 .

The explanatory variables of the model express $21.4 \%$ of the variations occurring in the MTI. It is noted that the explanatory power is not very high, but it agrees 
with the results obtained by Guillamón, Bastida and Benito (2011) and Tavares and Cruz (2014), respectively to $29 \%$ and $25 \%$.

The results of the F test $(10,605)=34.23$ allow the conclusion that, for a $1 \%$ level of significance, there is a sufficient statistical evidence to state that the regressors present values different from zero and as a whole explain satisfactorily the variations found in the MTI.

Considering the previous results, tests were made to analyse a possible violation of the model's assumptions. Concerning multicollinearity, no variable was found to present a VIF value above 10, which indicates a non-violation of the assumption. Nor the $1 / \mathrm{VIF}$ values of tolerance are close to zero, showing that the regression coefficients are stable, both in magnitude and sign (Marôco, 2010).

Tab. 2: Results of the multiple linear regression model (MTI)

\begin{tabular}{|c|c|c|c|c|}
\hline Variable & $\begin{array}{l}\text { MTI } \\
\text { SOCDEM } \\
(1)\end{array}$ & $\begin{array}{l}\text { MTI } \\
\text { POL } \\
(2)\end{array}$ & $\begin{array}{l}\text { MTI } \\
\text { ECOFIN } \\
(3) \\
\end{array}$ & $\begin{array}{l}\text { MTI } \\
\text { SOCDEM_POL_ECOFIN } \\
\text { (4) }\end{array}$ \\
\hline DIM & $\begin{array}{l}2,237 * * * \\
(3.60)\end{array}$ & & & $\begin{array}{l}1,588 * * \\
(2.52)\end{array}$ \\
\hline INTER1574 & $\begin{array}{l}1,653 * * * \\
(3.09)\end{array}$ & & & $\begin{array}{l}1,668 * * * \\
(3.15)\end{array}$ \\
\hline ESCOL & $\begin{array}{l}0.340 * * \\
(2.43)\end{array}$ & & & $\begin{array}{l}0.184 \\
(1.10)\end{array}$ \\
\hline IENV & $\begin{array}{l}-0.000866 \\
(-0.16)\end{array}$ & & & $\begin{array}{l}0.000777 \\
(0.15)\end{array}$ \\
\hline TXDESEMP & $\begin{array}{l}-0.361 * * \\
(-2.56)\end{array}$ & & & $\begin{array}{l}-0.411 * * * \\
(-2.83)\end{array}$ \\
\hline FGOV & & $\begin{array}{l}1,704 \\
(0.83)\end{array}$ & & $\begin{array}{l}1,199 \\
(0.58)\end{array}$ \\
\hline IDEOL & & $\begin{array}{l}-0.624 \\
(-0.71)\end{array}$ & & $\begin{array}{l}-0.792 \\
(-0.95)\end{array}$ \\
\hline PARTELEI & & $\begin{array}{l}-0.411 * * * \\
(-8.60)\end{array}$ & & $\begin{array}{l}-0.0577 \\
(-0.92)\end{array}$ \\
\hline AUTFIN & & & $\begin{array}{l}24.90 * * * \\
(10.17)\end{array}$ & $\begin{array}{l}7,079 * \\
(1.75)\end{array}$ \\
\hline ENDLIQ & & & $\begin{array}{l}0.00224 * * * \\
(4.37)\end{array}$ & $\begin{array}{l}0.00302 * * * \\
(5.46)\end{array}$ \\
\hline _cons & $\begin{array}{l}-1,076 \\
(-0.20)\end{array}$ & $\begin{array}{l}57.17 * * * \\
(18.04)\end{array}$ & $\begin{array}{l}24.84 * * * \\
(25.28)\end{array}$ & $\begin{array}{l}6,861 \\
(0.90)\end{array}$ \\
\hline $\mathrm{F}$ & $18.61 * * *$ & $56.16^{* * * *}$ & $25.90 * * *$ & $34.23 * * *$ \\
\hline $\mathrm{R}^{2}$ & 0.205 & 0.103 & 0.142 & 0.214 \\
\hline $\mathrm{N}$ & 616 & 616 & 616 & 616 \\
\hline
\end{tabular}

Source: Authors own elaboration.

Note: ${ }^{*} \mathrm{p}<0.10,{ }^{* *} \mathrm{p}<0.05, * * * \mathrm{p}<0.01$. 
To test for heteroscedasticity, the White test was used. As the test statistic is 77.52 above the $p$-value $=0.1032$, it is concluded that the assumption of heteroscedasticity was not violated.

Autocorrelation of errors was carried out using the Durbin-Watson test, reaching the conclusion that the model does not suffer from error autocorrelation.

The results obtained reveal that for the maximum level of significance of $10 \%$, the variables of DIM, INTER1574, TXDESEMP, AUTFIN and ENDLIQ are statistically significant.

The obtained results will now be discussed. Based on the agency theory, voters (principal) elect with their votes politicians/leaders (agents) to represent their interests through policies, proposed by governments and instructions given to Public Administration on how to carry them out.

As there is information asymmetry between agents and the principal, based on the results obtained it is important to discuss which socio-demographic, political and economic-financial factors determine the transparency in public management of local authorities.

Out of the ten research hypotheses formulated, the results obtained allow us to validate five.

Validation of $\mathbf{H}_{1}$ corroborates the idea that municipal authorities are more transparent in larger councils. This result agrees with those obtained by GallegoÁlvarez, Rodríguez-Domínguez and García-Sánchez (2010), Guillamón, Bastida and Benito (2011), Esteller-Moré and Otero (2012), Sol (2013), Mendes (2012), Pires (2012), Batalha (2014) and Sedmihradská (2015).

The results obtained also confirm that the wider the population with access to the internet, the higher the local authority transparency, and so $\mathbf{H}_{2}$ is also validated. Easy access to the internet increases the possibility of access to information about the local authority. In this context, citizens seem to be closer to local authorities.

The hypothesis related to the unemployment rate is also corroborated, and so $\mathbf{H}_{5}$ is also validated. This result is consistent with that obtained by Alegre et al. (2013), Tavares and Cruz (2014) and Batalha (2014). There seems to be the underlying idea that, on one hand, the more precarious the council's economic situation, the greater the temptation for local authorities to conceal this fact. On the other hand, the unemployed population may have many other personal worries, and is therefore less concerned about seeking information on the local authority, outside the area of employment.

In relation to economic-financial factors, the results allow validation of the two hypotheses defined. Therefore, $\mathbf{H}_{\mathbf{9}}$ is validated, corroborating the opinions of Tavares and Cruz (2014), Alegre et al. (2013) and Vicente, Benito and Bastida (2013). Here, we find that local authorities with higher financial autonomy, 
possibly even able to charge more taxes, feel the need to inform citizens, and so they are more transparent. This fact may contribute to citizens not feeling they are paying high taxes as they may have a precise idea of municipal management.

The results obtained also allow the validation of $\mathbf{H}_{\mathbf{1 0}}$, corroborating those obtained by Rueda (2007), García and García (2008), Pires (2012) and Batalha (2014). Here, there seems to be statistical evidence confirming that greater net debt leads local authorities to be more transparent. There is a general opinion that such a result can be explained by local authorities wanting to pacify citizens.

Finally, it is underlined that no results were found to allow validation of the hypotheses related to political factors $\left(\mathbf{H}_{6}, \mathbf{H}_{7} \& \mathbf{H}_{\mathbf{8}}\right)$.

\section{Conclusion}

Recent studies in the field of Public Administration have highlighted the role of transparency in making information available to citizens, allowing them to participate in the political process, as well as promoting accountability, improving the quality of government decision-making and assisting to anticipate and lessen corruption. The information provided can reveal private interests that may go against the collective interest and hold actors responsible for all decisions and measures taken or omitted.

This study contributes to scientific knowledge by investigating the determinants of local government transparency, seeking to answer on the specific case of the Portuguese situation the following research question: "what are the factors determining transparency in public management of Portuguese local authorities". In particular, the intention was to identify which factors determine the level of transparency in public management of Portuguese local authorities. To this end, a set of hypotheses were tested, considering the 308 Portuguese local authorities. Use was made of the results of the recently developed MTI for 2013 and 2014. The study was based on the agency theory, considering the agency relationships applied to voters/tax-payers (principal) and politicians/leaders of local administration (agent).

In general terms, the results obtained identify as the explanatory determinants of transparency in public management of Portuguese local authorities: the population size, individuals aged between 15 and 74 who use the internet, the unemployment rate, financial autonomy and the net debt. No results were obtained allowing validation of the hypotheses related to the level of education, aging index or political factors (form of governance, political ideology and political/voter participation).

Finally, it is highlighted that this research aimed to make a significant contribution to the literature studying the determinants of transparency in public management 
Ribeiro, N. - Nogueira, S. - Freitas, I.: Transparency in Portuguese Local Government: A Study of its Determinants.

of Portuguese local authorities, largely due to the limited number of studies carried out in this area, and particularly considering the MTI.

\section{References}

Alegre, J., Peñas, L., Santias, F., Boubeta, A., 2013. Budget transparency in local governments: an empirical analysis. Local Government Studies 2, 182-207. DOI: 10.1080/03003930.2012.693075.

Alt, J., 2006. The causes of fiscal transparency: Evidence from the U.S. states. IMF Staff Papers 53, International Monetary Fund, 30-57.

Alt, J., Lassen, D., Skilling, D., 2001. Fiscal transparency, gubernatorial popularity and the scale of government: Evidence from the States. State Politics \& Policy Quarterly 3, 230-250. DOI: 10.1177/153244000200200302.

Batalha, S., 2014. Determinantes da transparência municipal em Portugal: uma análise empírica. Dissertação de Mestrado em Economia e Políticas Públicas, Instituto Superior de Economia e Gestão. Available from: <http://hdl.handle.net/ 10400.5/8491>. [6 January 2016].

Christoph, A., Schaltegger, C., Torgler, B., 2007. Government accountability and fiscal discipline: A panel analysis using Swiss data. Journal of Public Economics 1-2, 117-140. DOI: 10.1016/j.jpubeco.2006.07.003.

Esteller-Moré, A., Otero, J., 2012. Fiscal transparency: (Why) Does your local government respond? Public Management Review 8, 1153-1173. DOI: 10.1080/14719037.2012.657839.

Ferejohn, J., 1986. Incumbent Performance and Electoral Control. Public Choice 1-3, 5-25. DOI: 10.1007/bf00124924.

Ferejohn, J., 1999. Accountability and authority: Towards a model of political accountability. Democracy, Accountability and Representation, 131-153. DOI: 10.1017/cbo9781139175104.005.

Gallego-Álvarez, I., Rodríguez-Domínguez, L., García-Sánchez, I., 2010. Are determining factors of municipal E-government common to a worldwide municipal view? An intra-country comparison. Government Information Quarterly 4, 423-430. DOI: 10.1016/j.giq.2009.12.011.

García, A., García, J., 2008. Determinantes de la divulgación de information contables a través de Internet por parte de los gobiernos locales. Revista Española de Financiación y Contabilidad 137, 63-84. DOI: 10.1080/02102412.2008. 10779639.

García-Sánchez, I., Frías-Aceituno, J., Rodríguez-Domínguez, L., 2013. Determinants of corporate social disclosure in Spanish local governments. Journal of Cleaner Production 39, 60-72. DOI: 10.1016/j.jclepro.2012.08.037. 
Guillamón, M., Bastida, F., Benito, B., 2011. The determinants of local government's financial transparency. Local Government Studies 4, 391-406. DOI: 10.1080/03003930.2011.588704.

Ingram, R., Copeland, R., 1982. Municipal market measure and reporting practices: An extension. Journal of Accounting Research 20, 766-772. DOI: $10.2307 / 2490900$.

Jensen, M., Meckling, W., 1976. Theory of the firm: managerial behavior, agency costs and ownership structure. Journal of Financial Economics 4, 305-360. DOI: 10.1016/0304-405x(76)90026-x.

Lourenço, R., Jorge, S., Sá, P., Rolas, H., 2011. Transparência financeira das autarquias locais: Informação disponibilizada nos sítios web 4. Instituto de Engenharia de Sistemas e Computadores de Coimbra.

Marôco, J., 2010. Análise estatística com o PASW Statistics. ReportNumber, Pêro Pinheiro.

Mendes, H., 2012. Divulgação da informação financeira via internet das autarquias locais. Dissertação de mestrado em Contabilidade e Administração Pública. Universidade de Aveiro. Available from: <https://ria.ua.pt/bitstream/10773/ 10589/1/disserta\%C3\%A7\%C3\%A3o.pdf>. [4 April 2016].

Piotrowski, S., Van Ryzin, G., 2007. Citizen Attitudes toward Transparency in Local Government. The American Review of Public Administration 3, 306-323. DOI: $10.1177 / 0275074006296777$.

Pires, W., 2012. Os determinantes da divulgação da informação financeira na Internet: Evidência empírica nos municípios portugueses. Dissertação de mestrado em Contabilidade e Finanças. Instituto Politécnico de Bragança. Available from: <http://hdl.handle.net/10198/8482>. [2 September 2015].

Reddick, C., 2005. Citizen interaction with e-government: From the streets to servers? Government Information Quarterly 1, 38-57. DOI: 10.1016/j.giq. 2004.10.003.

Rueda, M., 2007. Publicación de información financeira en Internet. Un modelo de ecuaciones estructurales aplicado a las entidades locales. Facultad de ciências económicas y empresariales, Saragoza (Espanha). Available from: <http://www.jstor.org/stable/42784200> [24 October 2015].

Sedmihradská, L., 2015. Budget Transparency in Czech Local Government. Procedia Economics and Finance 25, 598-606. DOI: 10.1016/s22125671(15)00774-1.

Sol, D., 2013. The institutional, economic and social determinants of local government transparency. Journal of Economic Policy Reform 1, 90-107. DOI: 10.1080/17487870.2012.759422. 
Ribeiro, N. - Nogueira, S. - Freitas, I.: Transparency in Portuguese Local Government: A Study of its Determinants.

Tavares, A., Cruz, N., 2014. The determinants of local government transparency: a preliminary analysis. Proceedings of the 8th International Conference on Theory and Practice of Electronic Governance - ICEGOV '14. DOI: 10.1145/2691195.2691291.

Tavares, A., Rodrigues, M., 2012. Os instrumentos de participação política e administrativa a nível local: Uma análise empírica das escolhas dos municípios portugueses. Congresso da Associação Portuguesa de Ciência Política. Available from: <http://hdl.handle.net/10198/8730>. [17 February 2015].

Traunmuller, R., 2001. Relevance of portals in e-government. 14th Bled Electronic Commerce Conference, Slovenia, 35-45.

Vicente, C., Benito, B., Bastida, F., 2013. Transparency and political budget cycles at municipal level. Swiss Political Science Review 2, 139-156. DOI: 10.1111/spsr.12036. 